\title{
Assessment of the neutrophil to lymphocyte ratio in young patients with acute coronary syndromes
}

\author{
Akut koroner sendromlu genç hastalarda \\ nötrofil lenfosit oranının değerlendirilmesi
}

\author{
Serkan Öztürk, M.D., Alim Erdem, M.D., Mehmet Fatih Özlü, M.D., Selim Ayhan, M.D., \\ Kemalettin Erdem, M.D.," Mehmet Özyaşar, M.D., Yusuf Aslantaş, M.D., ${ }^{*}$ Mehmet Yazıcı, M.D. \\ Departments of Cardiology, "Cardiovascular Surgery, Abant Izzet Baysal University Faculty of Medicine, Bolu; \\ *Department of Cardiology, Duzce University Faculty of Medicine, Düzce
}

\section{ABSTRACT}

Objectives: It is well known that inflammation plays a key role in both initiation and propagation of acute coronary syndrome (ACS). White blood cell (WBC) and its subtypes are an indicator of inflammation in patients with ACS. We aimed to evaluate the WBC and its subtypes in patients aged $<45$ year with acute coronary syndromes.

Study design: We retrospectively analyzed WBC and its subtypes (including neutrophil and lymphocyte) in 84 patients ( $<45$ year) who were admitted to the emergency department for chest pain suggestive of ACS (44 unstable angina pectoris, 40 non-ST-segment elevation myocardial infarction [NSTEMI]), and 40 healthy controls.

Results: Hypertension, diabetes mellitus, smoking, and family history were significantly higher in NSTE-ACS patients. Also, LDL levels was significantly higher and HDL levels was significantly lower in NSTE-ACS patients $(p=0.041$ and $p=0.009)$. The difference in percent of lymphocytes between the groups was significant $(p=0.048)$. N/L ratio was significantly different between all groups and between the NSTEMI and USAP $(p<0.001$ and $p=0.041)$. Our results demonstrated that hypertension, percent of neutrophils, and $\mathrm{N} / \mathrm{L}$ ratio was a significant independent predictor of NSTE-ACS (Beta $=0.251,95 \%$ $\mathrm{Cl}=0.002-0.523, \mathrm{p}=0.048$; beta $=0.561,95 \% \mathrm{Cl}=0.008-0.137$, $\mathrm{p}=0.028$ and beta $=0.260,95 \% \mathrm{Cl}=0.042-0.438, \mathrm{p}=0.018$, respectively).

Conclusion: N/L was found to be elevated in young patients with NSTE-ACS compared with control group. The inflammation assessed using WBC and its subtypes may be more important in young NSTE-ACS patients.

\section{ÖZET}

Amaç: Enflamasyonun akut koroner sendrom (AKS) oluşumunda ve ilerlemesinde önemli bir rol oynadığı bilinmektedir. Beyaz kan hücresi ve alt tipleri AKS'li hastalarda enflamasyonun bir göstergesidir. Bu çalışmada, beyaz kan hücresi ve alt tiplerinin $<45$ yaş genç hastalarda AKS ile ilişkisinin değerlendirilmesi amaçlandı.

Çalışma planı: Göğüs ağrısı şikâyetiyle acil servise başvuran ST yükselmesi olmayan AKS'li (STYz-AKS) 84 genç (<45 yıl) hastanın (40 ST yükselmesiz miyokart enfarktüslü [STYzME], 44 kararsız anjina pektoris) ve 40 kişilik kontrol grubunun beyaz kan hücresi ve alt tipleri olan nötrofil ve lenfosit oranları geriye dönük olarak incelendi.

Bulgular: STYz-AKS'li hastalarda hipertansiyon, diabetes mellitus, sigara kullanımı ve aile öyküsü anlamlı olarak daha yüksekti. Bu grupta ayrıca LDL seviyeleri anlamlı olarak yüksek ve HDL seviyeleri anlamlı olarak düşük bulundu $(p=0.041$ ve $p=0.009$ ). Gruplar arasında lenfosit oranları anlamlı olarak farklıydı ( $p=0.048)$. Tüm gruplar arasında ve STYzME'li ile kararsız anjina pektorisli gruplar arasında N/L oranı anlamlı olarak farklı bulundu $(p<0.001$ ve $p=0.041)$. Ayrıca, çok değişkenli doğrusal regresyon analizinde hipertansiyonun, nötrofil yüzdesinin ve N/L oranının STYz-AKS için bağımsız öngördürücüler olduğu gösterildi (sırasıyla, beta=0.251, \%95 GA=0.0020.523, $p=0.048$; beta $=0.561, \% 95 \mathrm{GA}=0.008-0.137, \mathrm{p}=0.028$ ve beta=0.260, \%95 $\mathrm{GA}=0.042-0.438, \mathrm{p}=0.018$ ).

Sonuç: N/L oranı, STYz-AKS'li genç hastalarda kontrol grubundan daha yüksek bulunmuştur. Genç STYz-AKS'li hastalarda enflamasyonun beyaz kan hücreleri ve alt tipleri ile değerlendirilmesi daha da önemli rol oynayabilir.

Received: August 04, 2012 Accepted: December 27, 2012

Correspondence: Dr. Serkan Öztürk. Abant İzzet Baysal Üniversitesi Tıp Fakültesi, Kardiyoloji Anabilim Dalı, 14280 Bolu, Turkey.

Tel: +90 374 - 2534656 e-mail: drserkan69@ hotmail.com 
$\mathrm{T}$ he total white blood cell (WBC) count and its subtypes, neutrophil count, and neutrophil to lymphocyte (N/L) ratio represent the balance between neutrophil and lymphocyte levels in the body and can be indicators of systemic inflammation. ${ }^{[1]}$ The N/L ratio has been shown to predict long-term mortality in patients admitted with ST-segment elevation myocardial infarction (STEMI). ${ }^{[2,3]}$ Also, it was reported that the N/L ratio was more closely associated with mortality than WBC in patients with stable and unstable coronary artery syndromes. ${ }^{[4,5]}$

Acute coronary syndrome (ACS), which may cause long-term disability and premature death, is most frequently seen in older people; however, its prevalence is increasing among young people. ${ }^{[6,7]}$ Additionally, the relation between the N/L ratio and young patients with ACS has not been assessed.

In this study, we evaluated N/L ratio and other clinical parameters in young patients with non ST-segment elevation myocardial infarction (NSTEMI) and unstable angina pectoris (USAP), in comparison with individuals with normal coronary arteries as controls.

\section{PATIENTS AND METHODS}

\section{Study population}

A total of 84 patients hospitalized within the first 24 hours of chest pain onset, younger than 45 years old, and diagnosed with ACS (40 NSTEMI: mean age $38.9 \pm 4.8$ years old; 44 USAP: mean age $38.4 \pm 4.9$ years old) were retrospectively analyzed in this study, using hospital registries. The N/L ratios of 40 patients younger than 45 years old and who underwent coronary angiography with a suspicion of coronary artery disease (CAD), revealing normal coronary arteries, were included into analysis as a control group. Patients who considered vasospasm and coagulation disorders were excluded from the study. Diagnosis of NSTEMI or USAP was made by triad criteria of chest pain, typical electrocardiographic findings, and/or elevation of cardiac enzymes. Only patients with the first acute coronary event were evaluated. The data related to age, hypertension, diabetes mellitus, smoking status, and family history as well as medical history, drug use, and body mass index (BMI) were obtained from hospital records. According to the report of seventh Joint National Committee (JNC), systolic blood pressure $\geq 140 \mathrm{mmHg}$ or diastolic $\geq 90 \mathrm{mmHg}$ was defined as hypertension. ${ }^{[8]}$ Diabetes was considered as fasting glucose value $\geq 126 \mathrm{mg} / \mathrm{dl}$ or those undergoing pharmacological treatment of diabetes. Status of smoking is stated as current smoker or nonsmokers. BMI was

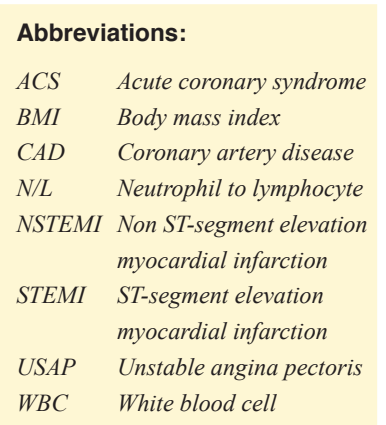
calculated using weight $(\mathrm{kg}) /$ height $(\mathrm{m})^{2}$. Obesity was defined if $B M I \geq 30 \mathrm{~kg} / \mathrm{m}^{2}$. Dislipidemia was defined if total cholesterol $>200 \mathrm{mg} / \mathrm{dl}$, LDL-cholesterol $>160$, and HDL-cholesterol $<40$ (for men) and $<50$ (for women). Family history of CAD was diagnosed if patients had a first degree male relative under 55 years of age or a female relative less than 65 years of age with CAD. Coronary angiography was performed by the Judkin's technique. Each coronary lesion that produce $50 \%$ stenosis in vessels $1.5 \mathrm{~mm}$ were scored separately and added together to present the overall Syntax score, which was calculated by the Syntax score algorithm. ${ }^{[9]}$ Permission for the study was obtained from local ethics committee of our institute.

\section{Laboratory analysis}

Hemoglobin, platelet, neutrophil, and lymphocyte count measurements were performed within approximately 60 minutes after blood sampling with Coulter LH 780 Analyzer and Coulter Hmx Hematology Analyzer (Beckman Coulter, Inc. CA, USA) with original method and reagents. LDL-C was calculated using the Friedewald formula. The other laboratory parameters were determined with standard protocols.

\section{Statistical analysis}

All analyses were performed using the SPSS for Windows 15.0 (SPSS Inc. IL, USA) software package. Continuous variables were presented as mean \pm standard deviation. Categorical variables were presented as percentages. All data were tested for normal distribution with the Kolmogorov-Smirnov test. The chi-square test, one-way ANOVA, and student$t$ test were used to test for differences in categorical variables. Pearson's and Spearmen's correlation exponents were used to force of relationship between continuous variables. Linear multiple regression analysis was used to evaluate the predictors of NSTEACS. A value of $p<0.05$ was considered statistically significant. 


\section{RESULTS}

The baseline characteristics of patients and their findings are shown in Table 1. Mean age and gender distribution between the groups were not different. The number of patients with hypertension, diabetes mel- litus, smoking, and family history was significantly higher in NSTE-ACS patients. Also, LDL levels were significantly higher and HDL levels were significantly lower in NSTE-ACS patients $(\mathrm{p}=0.041$ and $\mathrm{p}=0.009)$. There were significant differences in percent of lymphocytes $(\mathrm{p}=0.048), \mathrm{WBC}$, and percent of neutrophil

Table 1. Comparison of attributes between NSTE-ACS and healthy control patient groups

\begin{tabular}{|c|c|c|c|c|c|c|c|c|c|c|}
\hline & & SAP & $(n=44)$ & & STEM & $(n=40)$ & & Contro & $(n=40)$ & $p^{*}$ \\
\hline & $\mathrm{n}$ & $\%$ & Mean \pm SD & $\mathrm{n}$ & $\%$ & Mean \pm SD & $\mathrm{n}$ & $\%$ & Mean \pm SD & \\
\hline Age (years) & & & $38.4 \pm 4.9$ & & & $38.9 \pm 4.4$ & & & $39.8 \pm 3.9$ & 0.658 \\
\hline & & & & & & & & & & 0.757 \\
\hline Gender (male/female) & $30 / 14$ & & & $29 / 11$ & & & $28 / 12$ & & & 0.514 \\
\hline & & & & & & & & & & 0.319 \\
\hline Glucose (mg/dl) & & & $109.1 \pm 21.1$ & & & $111.5 \pm 22.7$ & & & $97.5 \pm 17.2$ & 0.147 \\
\hline & & & & & & & & & & 0.441 \\
\hline Hemoglobin (g/dl) & & & $13.8 \pm 3.1$ & & & $13.7 \pm 3.9$ & & & $13.9 \pm 3.4$ & 0.667 \\
\hline & & & & & & & & & & 0.745 \\
\hline White blood cell count $\left(x 10^{3}\right)$ & & & $11.8 \pm 3.1$ & & & $12.1 \pm 3.9$ & & & $8.9 \pm 3.4$ & 0.001 \\
\hline & & & & & & & & & & 0.211 \\
\hline Neutrophils (\%) & & & $63.8 \pm 16.2$ & & & $68.7 \pm 17.9$ & & & $55.8 \pm 13.4$ & 0.009 \\
\hline & & & & & & & & & & 0.103 \\
\hline Lymphocytes (\%) & & & $19.4 \pm 8.1$ & & & $18.9 \pm 8.9$ & & & $21.4 \pm 9.5$ & 0.048 \\
\hline & & & & & & & & & & 0.168 \\
\hline $\mathrm{N} / \mathrm{L}$ ratio & & & $3.31 \pm 0.91$ & & & $3.57 \pm 0.99$ & & & $2.61 \pm 0.64$ & $<0.001$ \\
\hline & & & & & & & & & & 0.041 \\
\hline Total cholesterol (mg/dl) & & & $193.4 \pm 56.8$ & & & $191.9 \pm 56.5$ & & & $177.1 \pm 44.1$ & 0.115 \\
\hline & & & & & & & & & & 0.442 \\
\hline LDL (mg/dl) & & & $128.8 \pm 34.9$ & & & $129.1 \pm 36.0$ & & & $104.9 \pm 26.5$ & 0.041 \\
\hline & & & & & & & & & & 0.622 \\
\hline $\mathrm{HDL}(\mathrm{mg} / \mathrm{dl})$ & & & $35.5 \pm 7.8$ & & & $34.7 \pm 8.3$ & & & $41.1 \pm 7.3$ & 0.009 \\
\hline & & & & & & & & & & 0.307 \\
\hline Triglyceride $(\mathrm{mg} / \mathrm{dl})$ & & & $154 \pm 101$ & & & $149 \pm 97$ & & & $143 \pm 58$ & 0.251 \\
\hline & & & & & & & & & & 0.469 \\
\hline Smoking & 27 & 61.3 & & 30 & 75.0 & & 16 & 40.0 & & 0.003 \\
\hline & & & & & & & & & & 0.101 \\
\hline Hypertension & 15 & 34.1 & & 17 & 42.5 & & 8 & 20.0 & & 0.026 \\
\hline & & & & & & & & & & 0.099 \\
\hline Diabetes mellitus & 5 & 11.3 & & 5 & 12.5 & & 1 & 2.5 & & 0.033 \\
\hline & & & & & & & & & & 0.619 \\
\hline Family history & 16 & 36.3 & & 22 & 55.0 & & 5 & 12.5 & & 0.007 \\
\hline & & & & & & & & & & 0.115 \\
\hline
\end{tabular}


between the groups (Table 1). N/L ratio was significantly different between all groups and between the NSTEMI and USAP $(\mathrm{p}<0.001$ and $\mathrm{p}=0.041$, Figure 1). Also $N / L$ ratio was significantly different between USAP and control group $(\mathrm{p}<0.001$, Figure 1$)$. The analysis of covariance including hypertension, diabetes mellitus, smoking, family history, and lipid parameters (LDL, HDL, total cholesterol, triglyceride) demonstrated that N/L ratio was significantly different between groups $(\mathrm{p}=0.021)$.

Analysis for age, other laboratory parameters, and prevalence of risk factors including hypertension, diabetes mellitus, smoking, family history, and sex distribution in subgroups showed that there were no significant differences between the NSTEMI and USAP patients (Table 1). Additionally there was a mildly positive correlation between $\mathrm{N} / \mathrm{L}$ ratio and overall SYNTAX score in patients with NSTEMI and USAP $(\mathrm{r}=0.19, \mathrm{p}=0.039)$.

In order to define the independent markers that predict NSTE-ACS, multivariable logistic regression analysis was performed (including hypertension, diabetes mellitus, family history, smoking, HDL, LDL, WBC, neutrophils, and N/L ratio), including data yielding significant differences $(\mathrm{p}<0.1)$. It was found that hypertension, percent of neutrophils, and $\mathrm{N} / \mathrm{L}$ ratio were significant independent predictors of NSTE-ACS (Beta $=0.251,95 \% \mathrm{CI}=0.002-0.523$, $\mathrm{p}=0.048$, beta $=0.561,95 \% \mathrm{CI}=0.008-0.137, \mathrm{p}=0.028$

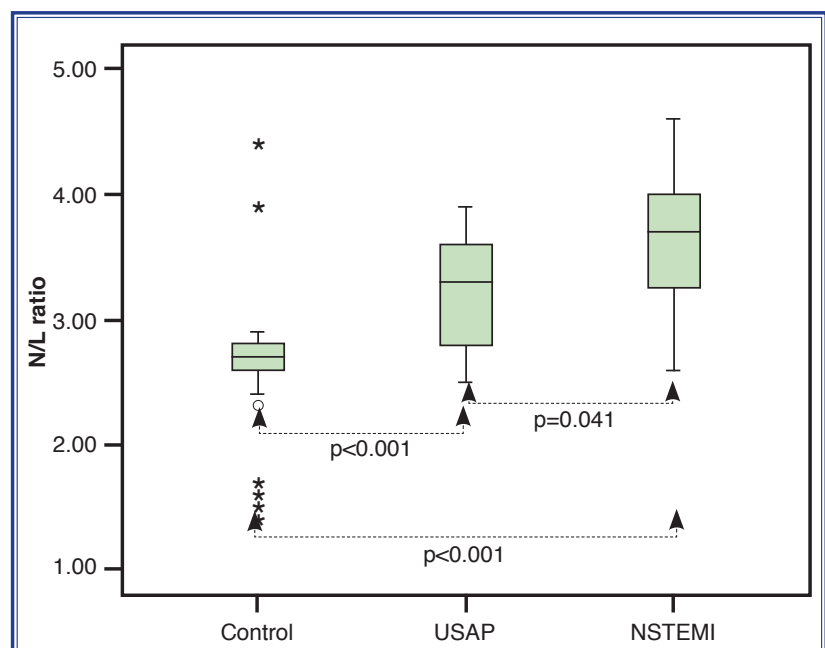

Figure 1. Comparison of N/L ratios among NSTEMI, USAP and control groups. N/L: Neutrophil to lymphocyte; USAP: Unstable angina pectoris; NSTEMI: Non ST-segment elevation myocardial infarction.
Table 2. Linear multivariate regression analysis of Independent predictors for NSTE-ACS

\begin{tabular}{lcc}
\hline Variables & $95 \% \mathrm{Cl}$ & $p$ \\
\hline Hypertension & $0.002-0.523$ & 0.048 \\
Diabetes & $-0.592-0.127$ & 0.201 \\
Smoking & $-0.287-0.192$ & 0.694 \\
Family history of NSTE-ACS & $-0.304-0.137$ & 0.450 \\
Low density lipoprotein & $-0.003-0.003$ & 0.852 \\
High density lipoprotein & $-0.028-0.006$ & 0.206 \\
White blood cell count & $-0.086-0.028$ & 0.315 \\
Neutrophil & $0.008-0.137$ & 0.028 \\
Neutrophil to lymphocyte ratio & $0.042-0.438$ & 0.018 \\
\hline
\end{tabular}

NSTE: Non ST-segment elevation; ACS: Acute coronary syndrome.

and beta $=0.260,95 \% \mathrm{CI}=0.042-0.438, \mathrm{p}=0.018$, respectively, Table 2).

\section{DISCUSSION}

Inflammation plays an important role at several stages of atherosclerosis. With a growing understanding of the role of inflammation in the atherosclerotic process, studies have focused on inflammatory markers for the evaluation of risk. ${ }^{[10]}$ There is an established relationship between inflammation and prothrombotic state in the literature. ${ }^{[11]} \mathrm{WBC}$ and subtypes of WBCs have an important role in modulating the inflammatory response in the atherosclerotic process. ${ }^{[12,13]}$ The main finding of our study was the elevated $\mathrm{N} / \mathrm{L}$ ratio in young NSTE-ACS patients compared with the control group. Also, a significant difference was detected between patients with USAP and NSTEMI.

The N/L ratio of body reflects the balance between neutrophil and lymphocyte levels in the body which is an indicator of systemic inflammation. ${ }^{[2,13]}$ The N/L ratio has been assessed in many studies about coronary artery disease and ACS. ${ }^{[4,13,14]}$ Recently published in a study, Kalay et al. ${ }^{[13]}$ demonstrated that the N/L ratio is associated with angiographic progression of the atherosclerotic process in patients with coronary artery disease. Papa et al. ${ }^{[4]}$ showed that a high N/L ratio was associated with increased cardiac mortality in clinically stable patients with coronary artery disease. Cho et al. ${ }^{[15]}$ evaluated the N/L ratio in early risk stratification of patients with STEMI and concluded that $\mathrm{N} / \mathrm{L}$ ratio is an independent predictor of six-month mortality. In our study, the N/L ratio was 
evaluated in young patients with ACS and was found to be associated with NSTEMI and USAP. Therefore, increased risk of ACS in young patients with high N/L ratio may be explained with the increased inflammation and progression of the atherosclerotic process.

Generally, young patients with coronary artery disease have multiple traditional risk factors and have a different risk profile than older patients. ${ }^{[16,17]}$ We have found that traditional risk factors such as hypertension, diabetes, smoking, dyslipidemia, and family history have a significantly higher prevalence in young patients with ACS. However, inflammation also plays an important role in both young and older patients. A previous study demonstrated that high CRP levels contributed to the risk of recurrent events, including all-cause mortality, and high fibrinogen levels are associated with all-cause mortality independent of cardiovascular risk factors in young patients. ${ }^{[18]}$

White blood cells play an important role in the inflammatory processes of atherosclerosis. ${ }^{[2]}$ Moreover, several studies have shown that they were associated with an increased number of leukocytes and ischemic events in patients with acute myocardial infarction. ${ }^{[19,20]}$ Recent data have demonstrated that elevated N/L ratio is the most powerful predictor of cardiovascular risk in patients with coronary artery disease. ${ }^{[2]}$ Additionally, lymphopenia is a common finding during stress reaction and has a fine discriminatory ability for diagnosis of ACS. ${ }^{[12,21]}$ We found decreased lymphocytes and increased WBC count in young patients with ACS. The major limitation of the study is retrospective design and relatively low number of patients. The lack of in-hospital and long-term follow-up was another limitation. In addition, WBC count and its subtypes were evaluated only once; however measurement of WBC, neutrophils, and lymphocytes after the acute phase could provide important data about inflammation and premature ACS.

In conclusion, $\mathrm{N} / \mathrm{L}$ ratio was found to be elevated in young patients with NSTE-ACS compared with control subjects. The inflammation assessed by WBC count and its subtypes may be more important in young patients with NSTE-ACS. Additional studies are needed to elucidate this relationship.

\section{Conflict-of-interest issues regarding the authorship or article: None declared}

\section{REFERENCES}

1. Zahorec R.Ratio of neutrophil to lymphocyte counts-rapid and simple parameter of systemic inflammation and stress in critically ill. Bratisl Lek Listy 2001;102:5-14.

2. Horne BD, Anderson JL, John JM, Weaver A, Bair TL, Jensen $\mathrm{KR}$, et al. Which white blood cell subtypes predict increased cardiovascular risk? J Am Coll Cardiol 2005;45:1638-43.

3. Núñez J, Núñez E, Bodí V, Sanchis J, Miñana G, Mainar L, et al. Usefulness of the neutrophil to lymphocyte ratio in predicting long-term mortality in ST segment elevation myocardial infarction. Am J Cardiol 2008;101:747-52. [CrossRef]

4. Papa A, Emdin M, Passino C, Michelassi C, Battaglia D, Cocci F. Predictive value of elevated neutrophil-lymphocyte ratio on cardiac mortality in patients with stable coronary artery disease. Clin Chim Acta 2008;395:27-31. [CrossRef]

5. Tamhane UU, Aneja S, Montgomery D, Rogers EK, Eagle KA, Gurm HS. Association between admission neutrophil to lymphocyte ratio and outcomes in patients with acute coronary syndrome. Am J Cardiol 2008;102:653-7. [CrossRef]

6. Carro A, Bastiaenen R, Kaski JC. Age related issues in reperfusion of myocardial infarction. Cardiovasc Drugs Ther 2011;25:139-48. [CrossRef]

7. Panduranga P, Sulaiman K, Al-Zakwani I, Abdelrahman S. Acute coronary syndrome in young adults from oman: results from the gulf registry of acute coronary events. Heart Views 2010;11:93-8. [CrossRef]

8. The seventh report of the Joint National Committee on prevention, detection and treatment of high blood pressure. NIH publication. No 3-5233. USA: National Institutes of Health; 2003.

9. SYNTAX working group. SYNTAX score calculator. Available at: http://www. syntaxscore.com. Accessed July, 2010.

10. Libby P, Ridker PM, Maseri A. Inflammation and atherosclerosis. Circulation 2002;105:1135-43. [CrossRef]

11. Kaya MG, Akpek M, Elcik D, Kalay N, Yarlioglues M, Koc F, et al. Relation of left atrial spontaneous echocardiographic contrast in patients with mitral stenosis to inflammatory markers. Am J Cardiol 2012;109:851-5. [CrossRef]

12. Onsrud M, Thorsby E. Influence of in vivo hydrocortisone on some human blood lymphocyte subpopulations. I. Effect on natural killer cell activity. Scand J Immunol 1981;13:573-9.

13. Kalay N, Dogdu O, Koc F, Yarlioglues M, Ardic I, Akpek M, et al. Hematologic parameters and angiographic progression of coronary atherosclerosis. Angiology 2012;63:213-7.

14. Duffy BK, Gurm HS, Rajagopal V, Gupta R, Ellis SG, Bhatt DL. Usefulness of an elevated neutrophil to lymphocyte ratio in predicting long-term mortality after percutaneous coronary intervention. Am J Cardiol 2006;97:993-6. [CrossRef]

15. Cho KH, Jeong MH, Ahmed K, Hachinohe D, Choi HS, Chang SY, et al. Value of early risk stratification using hemoglobin level and neutrophil-to-lymphocyte ratio in patients with STelevation myocardial infarction undergoing primary percuta- 
neous coronary intervention. Am J Cardiol 2011;107:849-56.

16. Núñez J, Núñez E, Bodí V, Sanchis J, Miñana G, Mainar L, et al. Usefulness of the neutrophil to lymphocyte ratio in predicting long-term mortality in ST segment elevation myocardial infarction. Am J Cardiol 2008;101:747-52. [CrossRef]

17. Lee PC, Kini AS, Ahsan C, Fisher E, Sharma SK. Anemia is an independent predictor of mortality after percutaneous coronary intervention. J Am Coll Cardiol 2004;44:541-6. [CrossRef]

18. van Loon JE, de Maat MP, Deckers JW, van Domburg RT, Leebeek FW. Prognostic markers in young patients with premature coronary heart disease. Atherosclerosis 2012;224:2137. [CrossRef]

19. Barron HV, Cannon CP, Murphy SA, Braunwald E, Gibson CM. Association between white blood cell count, epicardial blood flow, myocardial perfusion, and clinical outcomes in the setting of acute myocardial infarction: a thrombolysis in myocardial infarction 10 substudy. Circulation
2000;102:2329-34. [CrossRef]

20. Pellizzon GG, Dixon SR, Stone GW, Cox DA, Mattos L, Boura JA, et al. Relation of admission white blood cell count to long-term outcomes after primary coronary angioplasty for acute myocardial infarction (The Stent PAMI Trial). Am J Cardiol 2003;91:729-31. [CrossRef]

21. Thomson SP, Gibbons RJ, Smars PA, Suman VJ, Pierre RV, Santrach PJ, et al. Incremental value of the leukocyte differential and the rapid creatine kinase-MB isoenzyme for the early diagnosis of myocardial infarction. Ann Intern Med 1995;122:335-41. [CrossRef]

Key words: Acute coronary syndrome; aged; coronary angiography; coronary artery disease; hemoglobins/metabolism; erythrocyte indices; inflammation; leukocytes.

Anahtar sözcükler: Akut koroner sendrom; yaş; koroner anjiyografi; koroner arter hastalığı; hemoglobin/metabolizma; eritrosit indeksi; enflamasyon; lökosit. 